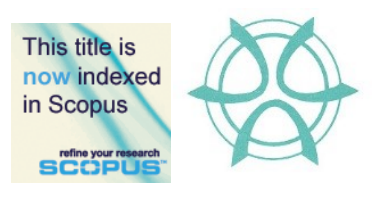

PLANNING MALAYSIA:

Journal of the Malaysian Institute of Planners

VOLUME 19 ISSUE 5 (2021), Page $76-87$

\title{
POST-CONSERVATION EVALUATION (PCE) ON HISTORIC BUILDINGS: AUTHENTICITY OF ADAPTIVE REUSE MUSEUMS IN GEORGE TOWN, UNESCO WORLD HERITAGE SITE
}

\author{
Muhammad Firzan Abdul Aziz ${ }^{1}$ \\ ${ }^{1}$ School of Housing, Building and Planning \\ UNIVERSITI SAINS MALAYSIA
}

\begin{abstract}
Adaptive reuse has apparently become a favourable means of built heritage conservation in the UNESCO World Heritage Site (WHS) of Melaka and George Town. In most cases, adaptive reuse implementations inflict conflicting demands to historic buildings in terms of meeting new functional needs and retaining physical authenticity. Inappropriate implementation of adaptive reuse for historic buildings within WHS may result in the violation of Outstanding Universal Values (OUVs). The purpose of this study is to determine the authenticity condition of historic buildings on their post-conservation phase, after adaptive reuse implementation. Five historic buildings namely the Penang State Museum (PSM), Made in Penang Interactive Museum (MIPIM), Sun Yat Sen Museum (SYSM), Batik Painting Museum (BPM) and Dark Mansion-3D Glow in the Dark Museum (DM) were evaluated through field observation. In accommodating the museum function, three elements were found to be intervened inappropriately at these buildings namely the internal wall, windows, and building services. The findings of this evaluative study can be useful to technical review panels appointed by heritage authorities, in scrutinising heritage impact assessment (HIA) reports and evaluating future proposals concerning adaptive reuse projects of historic buildings within WHS.
\end{abstract}

Keywords: adaptive reuse museum, authenticity, city cultural heritage, historic building, post-conservation evaluation (PCE)

\footnotetext{
${ }^{1}$ Lecturer at Universiti Sains Malaysia. Email: firzan@usm.my
} 
PLANNING MALAYSIA

Journal of the Malaysia Institute of Planners (2021)

\section{INTRODUCTION}

Melaka and George Town are cultural sites of Malaysia that have been inscribed in the UNESCO World Heritage List on 7th July 2008. These two historic cities carry the brand as the UNESCO Historic Cities of the Straits of Malacca, for having Outstanding Universal Values (OUVs) for their historic landscape (Criterion II), cultural tradition (Criterion III), and outstanding built heritage (Criterion IV). Ever since the recognition, protection of both tangible and intangible heritage at the two cities turned mission-critical for local conservation stakeholders.

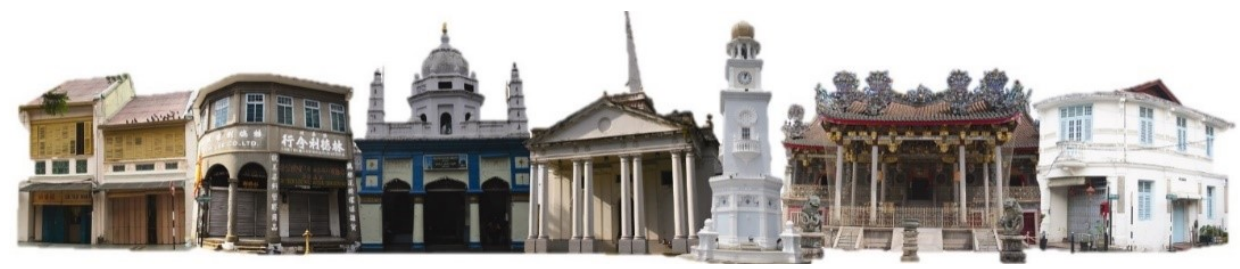

Figure 1: Unique architectural heritage without parallel anywhere in the East and Southeast Asia resulting from the influx of cultural elements from the Malay Archipelago, India, China, and Europe.

As shown in Figure 1, Melaka and George Town possess astonishing historic buildings which represent a superior quality of Malaysian built heritage scenery originated from both traditional and colonial architecture. Adherence to legal framework is thus an imperative aspect in operationalising conservation work for historic buildings (Kwong \& Badaruddin, 2017). Yet, numerous buildings in George Town failed to achieve so due to erroneous conservation practice (Zubir, 2017). In sensitising this matter, this study specifically focuses on evaluating the impact of historic buildings that have undergone adaptive reuse which typically incur physical interventions. Thus, the purpose of this study is to determine the authenticity condition of historic buildings on their postconservation phase, after adaptive reuse implementation. The following section discusses further on the aspects pertinent to understanding adaptive reuse and authenticity condition within the context of UNESCO World Heritage Site (WHS) and is manoeuvred to operationalise their evaluation.

\section{RESEARCH BACKGROUND}

UNESCO governs cultural places that have international significance which include heritage cities that dwell valuable historic buildings. As emphasised in the Operational Guidelines for the Implementation of the World Heritage Convention, authenticity and integrity are the two essential conditions that qualify a locality to be revered as a WHS (UNESCO, 2005). Maintenance of the two conditions must be based on the Outstanding Universal Value (OUV) of a 
Muhammad Firzan Abdul Aziz

Post-Conservation Evaluation (PCE) On Historic Buildings: Authenticity of Adaptive Reuse Museums in George Town, UNESCO World Heritage Site

site (Pendlebury et al., 2009; Nezhad et al., 2016). However, identifying and maintaining the authenticity and integrity conditions of cultural heritage sites are challenging (Alberts \& Hazen, 2010). Since integrity condition is beyond the scope of this paper, further discussion on the meaning of authenticity condition is hence imperative.

Authenticity remains the main principle for worldwide conservation works as advocated by numerous international charters, albeit its definition and concept have been controversial worldwide due to vagueness and embedded cultural assumptions (Alberts \& Hazen, 2010; Alho et. al., 2010). The term 'authenticity' is originated from the Greek word authenticos which means genuine and original. Authenticity depends on value judgements as it is related on the idea of truth or falsehood (Jamal \& Hill, 2004). There is a provocation made on the quality of authenticity in the sense that an original fabric can be authentic, but an authentic fabric is not necessarily original. Albeit its definition and concept have been controversial worldwide due to vagueness and embedded cultural assumptions, authenticity nevertheless remains the main principle for global conservation agendas and being advocated by numerous international charters (Alberts \& Hazen, 2010; Alho et al., 2010).

As stipulated in the Operational Guidelines for the Implementation of the World Heritage Convention (UNESCO, 2005), nomination of properties into the UNESCO World Heritage List necessitates the authenticity condition to be met for six out of the total ten OUV criteria namely from criteria (i) to criteria (vi). Authenticity is understood when cultural values of properties are truthfully and credibly expressed through attributes such as: form and design; materials and substance; use and function; traditions, techniques, and management systems; location and setting; language, and other forms of intangible heritage; spirit and feeling and miscellaneous internal and external factors. The meaning of authenticity then has been deepened to include further contexts. Authenticity is understood when cultural values of properties are truthfully and credibly expressed through attributes such as: i. Form and design, ii. Materials and substance, iii. Use and function, iv. Traditions, techniques and management systems, v. Location and setting, vi. Language, and other forms of intangible heritage, vii. Spirit and feeling and viii. Miscellaneous internal and external factors (UNESCO, 2005).

Nara Document on Authenticity (1994) is a conservation doctrine much related to authenticity. Within its Appendix 2, conservation is defined as all efforts designed to understand cultural heritage, know its history and meaning, ensure its material safeguard and as required, its presentation, restoration and enhancement (ICOMOS, 1994). In connecting to this sense, adaptive reuse, as a prevailing means of conservation effort in the current time, should legitimately conform to the benign philosophical criteria comprising minimal intervention, 
minimal loss of fabric, reversibility and legibility as mandated in various charters such as the New Zealand Charter 1992 (Article 4ii, 4iii), Bura Charter 1999 (Article 1.10, 3, 19-23) Deschambault Declaration 1982 (Article V-C), Appleton Charter 1983 (Article D) and Venice Charter 1964 (Article 12). Adaptive reuse perpetuates both retention and utilisation of historic buildings by making them physically intact, socially purposeful, and commercially viable in the contemporary age (Prihatmanti, Putri, \& Devina, 2017).

Communities perceived adaptive reuse of heritage properties as beneficial in meeting their sociocultural needs which includes self-growth, health benefit, social benefit, and cultural benefit $(\mathrm{Tu}, 2020)$. Whilst adaptive reuse is implied as the best possible option for achieving the twofold conservation philosophy: to simultaneously preserve and develop built heritage as highlighted in Abdul Aziz (2020), it can also be either a boon or bane for historic buildings judging from their post-conservation impacts. Without adhering to appropriate conservation philosophies and principles, the implementation of adaptive reuse on historic buildings may resulted in the violation of authenticity condition. Adaptive reuse has apparently become a favourable means of built heritage conservation in Melaka and George Town. Many historic buildings at the two historic cities have undergone adaptive reuse to boutique hotels, cafes and restaurants, pubs and bars, museums, galleries and so on (Ab Wahab, 2013). Out of these conversions, Mok (2013) reported that adaptation of historic buildings to museums is the most trending implementation, which latterly has involved both government and private premises.

The architecture of museums revolves around spaces that can be used to house specific museum functions such as exhibition and display, preventive and remedial active conservation, study, management, and receiving visitors. For having to reconcile those conflicting functions, museums have even been regarded as the most difficult type of building to be designed and constructed (Cassar, 1994). Implying from this, positive impacts resulting from the implementation of adaptive reuse on historic buildings are therefore essential and necessitated in the quest to retain the OUVs of Melaka and George Town.

Historic buildings housing museum function are considerably remarkable as a tangible heritage, since both of its structures and contents bear high historical, cultural, architectural, and aesthetical significance. Interestingly, such building was even considered as the largest museum artefact, for having heritage values embedded in its very physical built (Cassar, 1994). This hence calls upon the responsibility to conserve and manage them as a part of the OUVs (UNESCO, 2013), especially when the OUVs of any World Heritage must be maintained as at its time of inscription or enhanced in the future. Failure to do so may jeopardise the honour received as the World Heritage Committee will 
Muhammad Firzan Abdul Aziz

Post-Conservation Evaluation (PCE) On Historic Buildings: Authenticity of Adaptive Reuse Museums in George Town, UNESCO World Heritage Site

consider omitting any properties from the UNESCO World Heritage List if the OUV found destroyed (UNESCO, 2005).

Acknowledging that adaptive reuse of historic buildings may incur complexity and cause conflicting demands of meeting contemporary uses and expectations while obliged to retain cultural heritage values, post-conservation evaluation (PCE) on committed physical interventions can enlighten on building authenticity condition. In this regards, Ab Wahab's (2013) operational approach to assess adaptive reuse buildings is found contextually useful. Based on her approach, judgement of authenticity is made with reference to local conservation guidelines. She also considered the four criteria of authenticity stressed by ICCROM (1982) which include the aspects of material, design, workmanship and setting.

Ab Wahab's (2013) approach accentuated on the visual assessment of 16 building elements which include: i. Front façade, ii. External wall, iii. Internal wall, iv. Lower floor, v. Upper floor, vi. Column structure, vii. Staircase structure, viii. Roof structure, ix. Doors, x. Windows, xi. Roof finishes, xii. Ceiling finishes, xiii. Wall finishes, xiv. Floor finishes, xv. Building services and xvi. Architectural decorations. Collective assessment of these building elements is contributory to the overall judgement of a building. In connecting to this sense, the scale used in heritage impact assessment (HIA) for impact grading of cultural world heritage properties as shown in Table 1 can be useful match in creating a conclusive PCE on the authenticity of historic buildings that have undergone adaptive reuse implementation.

Table 1: Scale on impact grading used to indicate authenticity condition.

\begin{tabular}{cl}
\hline Impact Grading & \multicolumn{1}{c}{ Built Heritage Attributes } \\
\hline Major & $\begin{array}{l}\text { Change to key historic building elements that contribute to } \\
\text { OUV such that the resource is totally altered. } \\
\text { Comprehensive changes to the setting. }\end{array}$ \\
\hline \multirow{3}{*}{ Moderate } & $\begin{array}{l}\text { Changes to many key historic building elements, such that } \\
\text { the resource is significantly modified. } \\
\text { Changes to the setting of an historic building, such that it is } \\
\text { significantly modified. }\end{array}$ \\
\hline Minor & $\begin{array}{l}\text { Change to key historic building elements, such that the } \\
\text { asset is slightly different. } \\
\text { Change to setting of an historic building, such that it is } \\
\text { noticeably changed. }\end{array}$ \\
\hline Negligible & $\begin{array}{l}\text { Slight changes to historic building elements or setting that } \\
\text { hardly affect it. }\end{array}$ \\
\hline No change & No change to fabric or setting.
\end{tabular}


PLANNING MALAYSIA

Journal of the Malaysia Institute of Planners (2021)

\section{METHODOLOGY}

Site inventory was initially performed in George Town WHS to identify buildings that are suitable for accomplishing the objective of the study. Acknowledging that adaptation of historic buildings to museums is the most trending implementation (Mok, 2013) and museum is regarded as the most difficult type of building to be designed and constructed (Cassar, 1994), only historic buildings serving museum function were considered. Purposive sampling was then adopted to refine further the building selection process. Two inclusion criteria namely location and conservation were used for this. The former criterion only considered buildings located within the demarcated Core Zone and Buffer Zone of George Town WHS whereas the latter criterion merely considered buildings of cultural, historical or architectural importance that have undergone adaptive reuse implementation. Then, two exclusion criteria were applied where buildings that were nonoperational and not permissible for data collection got excluded from the selection process. In turn, five buildings made into the final list namely the Penang State Museum (PSM), Made in Penang Interactive Museum (MIPIM), Sun Yat Sen Museum (SYSM), Batik Painting Museum (BPM) and Dark Mansion-3D Glow in the Dark Museum (DM) as shown in Figure 2:

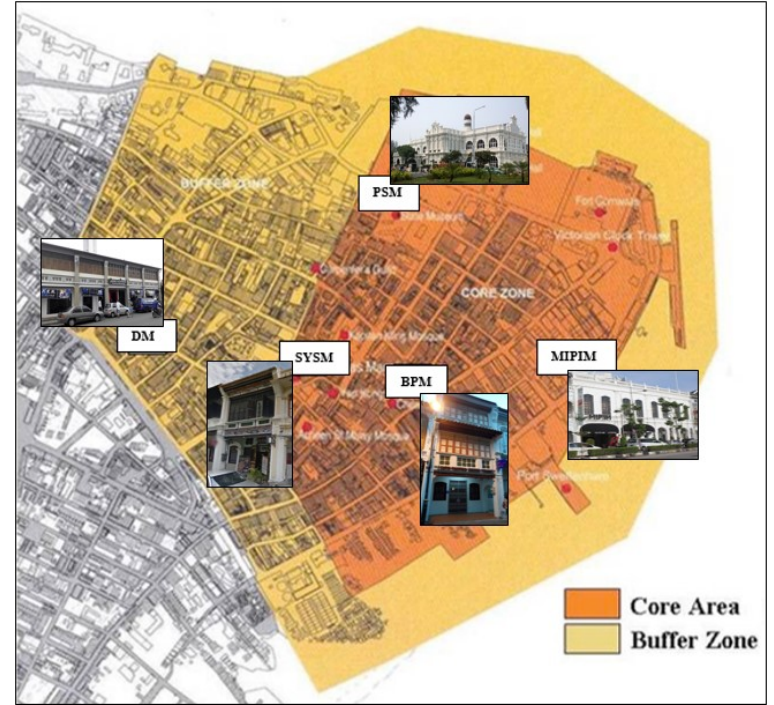

Figure 2: Location of the five shortlisted buildings within George Town WHS

Field observation was then conducted at PSM, MIPIM, SYSM, BPM and DM. It was done sequentially, starting from PSM to SYSM, BPM, MIPIM and finally DM within a month period collectively. Observation checklist comprising 16 building elements (used as collective indicators to represent the 
Muhammad Firzan Abdul Aziz

Post-Conservation Evaluation (PCE) On Historic Buildings: Authenticity of Adaptive Reuse Museums in George Town, UNESCO World Heritage Site

overall historic building unit) comprising: front façade, external wall, internal wall, lower floor, upper floor, columns structure, staircase structure, roof structure, doors, windows, roof finishes, ceiling finishes, wall finishes, floor finishes, building services, and architectural decorations was used, in line with Ab Wahab's (2013) assessment method.

These elements were individually and sequentially assessed at the five buildings, with the aid of a digital camera as well as a laptop computer for recording and storing both visual and textual data. During the field observation process, dichotomous labels of 'Yes' and 'No' were used to remark the state of authenticity for each building element investigated. The data entry was made onsite using the laptop computer mentioned. In making the judgement of whether each of the building element was authentic or inauthentic, local conservation guidelines as well as the four criteria of authenticity stressed by ICCROM were used as reference. Observation data obtained were then analysed using $\mathrm{Ab}$ Wahab's (2013) formula as the following:

Total no. of authentic building elements (Sum of indicators marked 'Yes')

Total no. of building elements (Sum of all indicators involved) $x 100$

Then, the percentage yielded based on the above formula was used to inform the level of authenticity condition. In line with the five scales of ICOMOS (2011) impact grading, the reference scales used to conclude the overall authenticity condition for individual building are listed in Table 2 as follows:

Table 2: Impact Grading

\begin{tabular}{ll}
\hline Reference Scale & Percentage \\
\hline Unsatisfactory & $0-19 \%$ \\
\hline Less satisfactory & $20-39 \%$ \\
\hline Moderate satisfactory & $40-59 \%$ \\
\hline Satisfactory & $60-79 \%$ \\
\hline High satisfactory & $80-100 \%$
\end{tabular}

\section{RESULTS AND DISCUSSION}

Table 3 presents the results on authenticity condition of the five buildings, categorised into non-shophouse (PSM and MIPIM) and shophouse (BPM, SYSM and DM) buildings. The results are organised to show retention of authenticity condition for each of their building element. The summative score and percentage are used to conclude the authenticity of each building. 
PLANNING MALAYSIA

Journal of the Malaysia Institute of Planners (2021)

Table 3: Results on authenticity condition.

\begin{tabular}{|c|c|c|c|c|c|}
\hline \multirow{3}{*}{$\begin{array}{l}\text { Historic Building } \\
\text { Elements }\end{array}$} & \multicolumn{5}{|c|}{ Authenticity Remarks } \\
\hline & \multicolumn{2}{|c|}{ Non- Shophouse Buildings } & \multicolumn{3}{|c|}{$\begin{array}{c}\text { Shophouse } \\
\text { Buildings }\end{array}$} \\
\hline & PSM & MIPIM & SYSM & BPM & DM \\
\hline A. Front façade & Yes & Yes & Yes & Yes & No \\
\hline B. $\quad$ External wall & No & No & Yes & Yes & No \\
\hline C. Internal wall & No & No & Yes & No & No \\
\hline D. Lower floor & No & Yes & Yes & Yes & No \\
\hline E. Upper floor & Yes & No & Yes & No & No \\
\hline $\begin{array}{ll}\text { F. } & \begin{array}{l}\text { Columns } \\
\text { structure }\end{array} \\
\end{array}$ & Yes & Yes & Yes & Yes & No \\
\hline G. $\begin{array}{l}\text { Staircase } \\
\text { structure }\end{array}$ & Yes & Yes & No & Yes & No \\
\hline H. Roof structure & Yes & Yes & No & No & Yes \\
\hline I. $\quad$ Doors & No & Yes & Yes & Yes & No \\
\hline J. $\quad$ Windows & No & No & Yes & Yes & No \\
\hline K. $\quad$ Roof finishes & Inaccessible & Inaccessible & Yes & No & Inaccessible \\
\hline $\begin{array}{ll}\text { L. } & \text { Ceiling } \\
\text { finishes }\end{array}$ & Yes & Yes & Yes & Yes & No \\
\hline M. Wall finishes & Yes & No & Yes & Yes & No \\
\hline N. Floor finishes & No & Yes & Yes & Yes & No \\
\hline $\begin{array}{ll}\text { O. } & \begin{array}{l}\text { Building } \\
\text { services }\end{array} \\
\end{array}$ & No & No & No & Yes & No \\
\hline $\begin{array}{ll}\text { P. } & \begin{array}{l}\text { Architectural } \\
\text { decorations }\end{array} \\
\end{array}$ & Yes & Yes & Yes & Yes & Yes \\
\hline $\begin{array}{c}\text { Summative Score } \\
\text { and Percentage }\end{array}$ & $08 / 15(53 \%)$ & $09 / 15(60 \%)$ & $13 / 16(81 \%)$ & $\begin{array}{l}12 / 16 \\
(75 \%)\end{array}$ & $02 / 15(13 \%)$ \\
\hline $\begin{array}{c}\text { Authenticity } \\
\text { Condition }\end{array}$ & $\begin{array}{c}\text { Moderate } \\
\text { satisfactory }\end{array}$ & Satisfactory & $\begin{array}{c}\text { High } \\
\text { satisfactory }\end{array}$ & Satisfactory & $\begin{array}{c}\text { Unsatisfactor } \\
\mathrm{y}\end{array}$ \\
\hline $\begin{array}{l}\text { Remarks: } \\
\text { Penang State Museu } \\
\text { (SYSM), Batik Paint }\end{array}$ & $\begin{array}{l}\text { PSM), Made } \\
\text { Museum (BPI }\end{array}$ & $\begin{array}{l}\text { Penang Inte } \\
\text { nd Dark Mar }\end{array}$ & $\begin{array}{l}\text { Museum } \\
\text { 3D Glow in }\end{array}$ & $\begin{array}{l}\text { IM), Sun Y } \\
\text { Dark Museun }\end{array}$ & $\begin{array}{l}\text { Sen Museum } \\
\text { DM) }\end{array}$ \\
\hline
\end{tabular}

Comparatively, SYSM recorded the highest percentage (81\%) of authenticity condition whereas DM recorded the lowest (13\%). These results can be linked with underlying factors such as building ownership, use history, and location. SYSM scored the best authenticity condition because the custodian of this building is a renowned historian who actively advocates for local heritage protection. It is inferred that sentimental value and sense of responsibility are vital factors contributing to the plausible authenticity retention of this SYSM since the building is inherited by the custodian. Apart from that, SYSM is situated in Armenian Street which is within the Core Zone of George Town WHS. This also explains the underlying cause of DM to have the lowest percentage of authenticity condition- associable with its location in Buffer Zone where conservation restrictions are relatively less restrictive. Besides, SYSM merely displays loose exhibitions such as collections of antique furniture and old artefacts hence the least physical intervention required. DM on the other hand has undergone some 
Muhammad Firzan Abdul Aziz

Post-Conservation Evaluation (PCE) On Historic Buildings: Authenticity of Adaptive Reuse Museums in George Town, UNESCO World Heritage Site

degree of physical interventions that were intrusive to its heritage fabric, in accommodating contemporary $3 \mathrm{D}$ glow in the dark exhibition. This claim is made based on comparing the current condition of the building against the four criteria of authenticity stressed by ICCROM (1982) which comprised of design, material, workmanship, and setting.

Looking on the categorical comparison, non-shophouse and shophouse buildings equally achieved moderate satisfactory for their authenticity conditions. By their percentage average, non-shophouse buildings (PSM and MIPIM) and shophouse buildings (SYSM, BPM and DM) recorded 56\% and 57\% respectively, with very slight difference between the two. However, the collective scoring as moderate satisfactory especially for shophouse buildings should be an eye-opener for heritage stakeholders and calls for better conservation measures since George Town WHS heavily depends on the heritage shophouses and townhouses- the building typology being mentioned explicitly in the OUV Criterion IV.

The results can also be significant for discussing elemental authenticity of the buildings. For the case of non-shophouse buildings, six building elements namely the front façade, column structure, staircase structure, roof structure, ceiling finishes and architectural decorations (indicators: A, F, G, H, L and P) were commonly found to be intervened appropriately. On the flipside, four building elements namely the external wall, internal wall, windows and building services (indicators: B, C, J and O) were commonly found to be intervened inappropriately. For the case of shophouse buildings, only one building element namely the architectural decorations (indicator: P) was commonly found to be intervened appropriately. It is in fact the same building element that was found to be intervened appropriately for all the five buildings scrutinised under this study.

Overall, the three building elements that were found to be intervened inappropriately are the internal wall, windows, and building services (indicators: $\mathrm{C}, \mathrm{J}$ and $\mathrm{O}$ ). Issues inflicting these three building elements are highlighted in Figure 3, 4 and 5 to show the areas affecting authenticity of historic buildings converted to museums in George Town WHS. Physical interventions made involving the three elements clearly have direct impact on the authenticity condition of adaptive reuse museums, calling for the serious needs of adhering and respecting to design, material, workmanship and setting criteria of authenticity as stressed by ICCROM (1982). 
PLANNING MALAYSIA

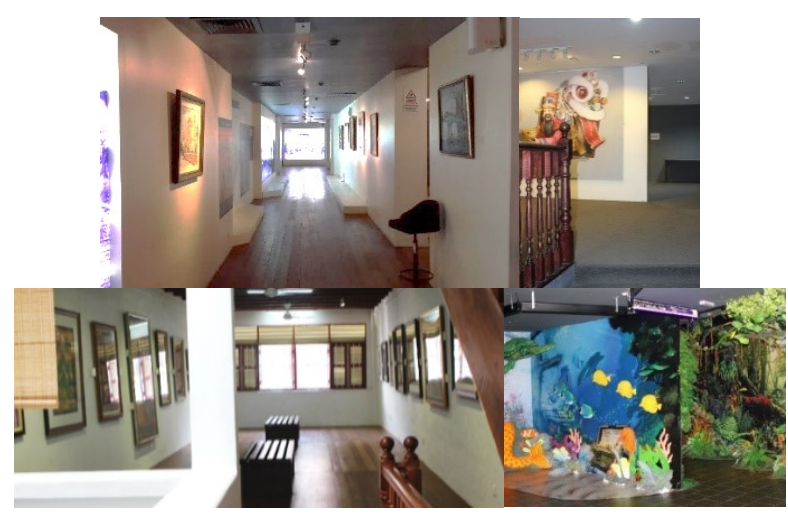

Figure 3: Insensitive installation of partitions, removal of original wall and extensive wall decorations were among the inappropriate physical interventions found involving internal wall element.

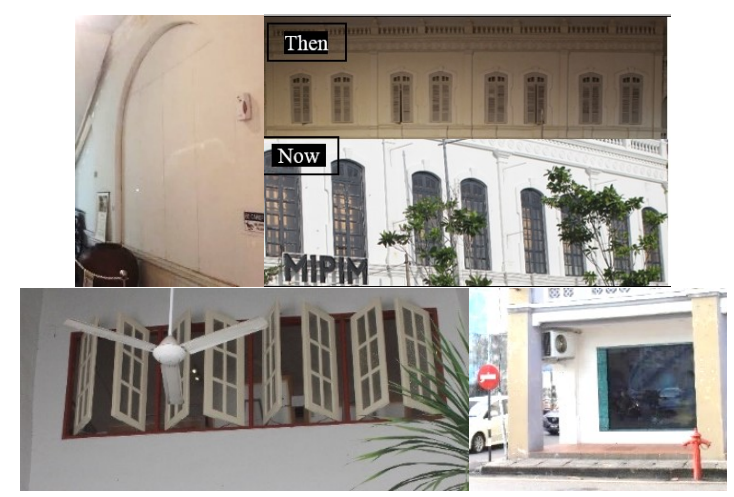

Figure 4: Fully enclosed original windows and replacement of non-harmonious modern windows were among the inappropriate physical interventions found on windows element.

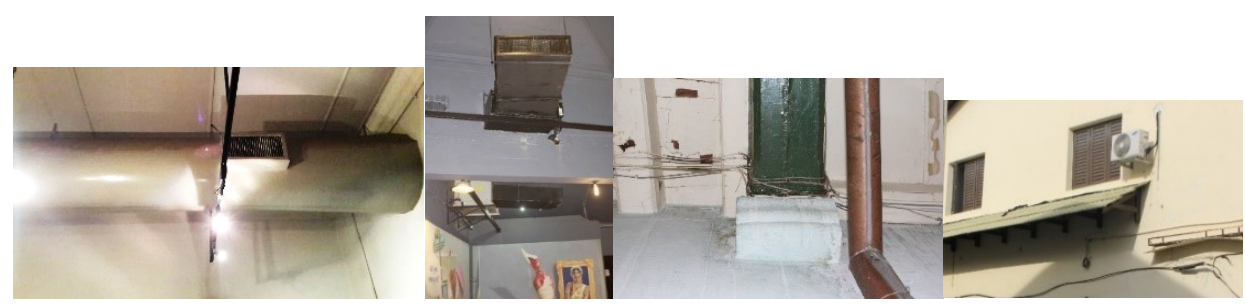

Figure 5: Intrusive installations, exposed electrical wiring and improper placement of air-conditioner compressors on building façade were among the inappropriate physical interventions found on building services element. 
Muhammad Firzan Abdul Aziz

Post-Conservation Evaluation (PCE) On Historic Buildings: Authenticity of Adaptive Reuse Museums in George Town, UNESCO World Heritage Site

\section{CONCLUSION}

Conversion of historic building to museum through adaptive reuse implementation demands a certain level of physical interventions to be made. Although such requirements are highly necessitated to retrofit museum function within historic building, post-conservation impact in the sense of physical appropriateness of heritage properties within WHS must never be taken for granted for the sake of OUV protection. Changes and modifications committed must not violate the four criteria of authenticity namely design, material, workmanship, and setting. It is hoped that the revelation on the three most affected building elements discovered through this evaluative study will be influential to decision-makers and heritage consultants. The PCE findings of this study can be specifically influential to technical review panels appointed by heritage authorities, in scrutinising HIA reports and evaluating future proposals concerning adaptive reuse projects involving historic buildings within WHS. Future studies can zoom further on the operational methods to re-visit and audit historic buildings that have undergone HIA process, by focusing the impacts at building scale (micro-assessment on individual unit).

\section{ACKNOWLEDGEMENTS}

The author would like to appreciate Universiti Sains Malaysia (USM) for funding this study under the Short-Term Grant (304/PPBGN/6315362), the School of Housing, Building and Planning, the mentors from Universiti Malaya as well as other parties that have directly and indirectly contributed to this study.

\section{REFERENCES}

Abdul Aziz, M. (2020). Post-Conservation Evaluation (PCE): Financial Performance of Adaptive Reuse Museums in George Town, Malaysia. Journal of the Malaysian Institute of Planners, 18(3), 25 - 34.

Ab Wahab, L. (2013). Application of adaptive re-use principles in the architectural elements of heritage hotel buildings in Melaka and George Town World Heritage sites. Unpublished doctoral dissertation. Penang, Malaysia: School of Housing, Building and Planning, University Science of Malaysia.

Alberts, H., \& Hazen, H. (2010). Maintaining authenticity and integrity at cultural World Heritage sites. The Geographical Review, 100(01), 56-73.

Alho, C., Morais, A., Mendes, J., \& Galvão, A. (2010). Authenticity criteria in conservation of historic buildings. 18th CIB World Building Congress, (pp. 188198). Salford, UK.

Cassar, M. (1994). Preventive conservation and building maintenance. Museum Management and Curatorship, 13(01), 39-47.

ICCROM. (1982). The Architectural Conservation Course. Rome: The International Centre for the Study of the Preservation and Restoration of Cultural Property .

ICOMOS. (1994). The Nara Document on Authenticity. International Council on Monuments and Sites. 
ICOMOS. (January, 2011). Guidance on Heritage Impact Assessment for Cultural World Heritage Properties. International Council on Monuments and Sites.

Jamal, T., \& Hill, S. (2004). Developing a framework for indicators of authenticity: The place and space of cultural and heritage tourism. Asia Pacific Journal of Tourism Research, 09(04), 353-371.

Kwong, A. T., \& Badaruddin, M. (December, 2017). Critical elements in refurbishment of dilapidated heritage buildings at George Town World Heritage Site in sustaining heritage tourism development. Journal of Tourism Research \& Hospitality, 1-12.

Mok, O. (2013). Museum hopping in George Town: The perfect history lesson. Retrieved from The Malay Mail Online: http://www.themalaymailonline.com/features/article/museum-hopping-ingeorge-town-the-perfect-history-lesson

Nezhad, S., Eshrati, P., \& Eshrati, D. (2016). Developing a conceptual framework of integrity in urban heritage conservation. Armanshahr Architecture \& Urban Development, 09(16), 95-104.

Pendlebury, J., Short, M., \& While, A. (2009). Urban World Heritage sites and the problem of authenticity. Cities, 26(06), 349-358.

Prihatmanti , R., Putri, C., \& Devina, A. (2017). Transforming Heritage Building for Commercialisation. Journal of the Malaysian Institute of Planners, 15(3), 135 146.

Tu, H.-M. (2020). The Attractiveness of Adaptive Heritage Reuse: A Theoretical Framework. Sustainability , 12(6), 2372.

UNESCO. (2005). Operational Guidelines for the Implementation of the World Heritage Convention. Paris: World Heritage Centre.

Zubir, Z. K. (2017). Rejuvenating the shophouse: Conservation of historical buildings in Penang's UNESCO World Heritage Site. International Journal of Heritage Architecture: Studies, Repairs and Maintenance, 2(2), 335-346.

Received: $5^{\text {th }}$ November 2021. Accepted: $5^{\text {th }}$ December 2021 